\title{
Transient receptor potential melastatin 4 channel contributes to migration of androgen-insensitive prostate cancer cells
}

\author{
Christian Holzmann ${ }^{1, *}$, Sven Kappel ${ }^{1,2, *}$, Tatiana Kilch ${ }^{1,2}$, Marcus Martin Jochum ${ }^{2,3}$, \\ Sabine Katharina Urban ${ }^{2,4}$, Volker Jung ${ }^{3}$, Michael Stöckle ${ }^{3}$, Karen Rother ${ }^{2,4}$, Markus \\ Greiner $^{2,4}$ and Christine Peinelt ${ }^{1,2}$ \\ ${ }^{1}$ Biophysics, Center for Integrative Physiology and Molecular Medicine, School of Medicine, Saarland University, Homburg, \\ Germany \\ ${ }^{2}$ Center of Human and Molecular Biology, Saarland University, Homburg, Germany \\ ${ }^{3}$ Clinics of Urology and Pediatric Urology, Saarland University, Homburg, Germany \\ ${ }^{4}$ Department of Medical Biochemistry and Molecular Biology, Saarland University, Homburg, Germany \\ * These authors have contributed equally to this work
}

Correspondence to: Christine Peinelt, email: christine.peinelt@uks.eu

Keywords: prostate cancer, cancer driver gene, transient receptor potential melastatin 4 channel (TRPM4), cell migration, Ca ${ }^{2+}$ signaling

Received: July 17, $2015 \quad$ Accepted: September 30, $2015 \quad$ Published: October 19, 2015

This is an open-access article distributed under the terms of the Creative Commons Attribution License, which permits unrestricted use, distribution, and reproduction in any medium, provided the original author and source are credited.

\section{ABSTRACT}

Impaired $\mathrm{Ca}^{2+}$ signaling in prostate cancer contributes to several cancer hallmarks, such as enhanced proliferation and migration and a decreased ability to induce apoptosis. $\mathrm{Na}^{+}$influx via transient receptor potential melastatin 4 channel (TRPM4) can reduce store-operated $\mathrm{Ca}^{2+}$ entry (SOCE) by decreasing the driving force for $\mathrm{Ca}^{2+}$. In patients with prostate cancer, gene expression of TRPM4 is elevated. Recently, TRPM4 was identified as a cancer driver gene in androgen-insensitive prostate cancer.

We investigated TRPM4 protein expression in cancer tissue samples from 20 patients with prostate cancer. We found elevated TRPM4 protein levels in prostatic intraepithelial neoplasia (PIN) and prostate cancer tissue compared to healthy tissue. In primary human prostate epithelial cells (hPEC) from healthy tissue and in the androgen-insensitive prostate cancer cell lines DU145 and PC3, TRPM4 mediated large $\mathrm{Na}^{+}$currents. We demonstrated significantly increased SOCE after siRNA targeting of TRPM4 in hPEC and DU145 cells. In addition, knockdown of TRPM4 reduced migration but not proliferation of DU145 and PC3 cells. Taken together, our data identify TRPM4 as a regulator of SOCE in hPEC and DU145 cells, demonstrate a role for TRPM4 in cancer cell migration and suggest that TRPM4 is a promising potential therapeutic target.

\section{INTRODUCTION}

In prostate cancer, decreased store-operated $\mathrm{Ca}^{2+}$ entry (SOCE) signals contribute to several hallmark functions of cancer, such as increased proliferation and migration and a reduction in the ability to induce apoptosis [1-4]. In addition, diminished $\mathrm{Ca}^{2+}$ signals impair degradation of the androgen receptor, a well-known target in prostate cancer chemotherapy [5]. Therefore, potential therapies that target $\mathrm{Ca}^{2+}$ homeostasis, including the SOCE pathway, are under active investigation [6]. The molecular key players of SOCE are STIM1 (stromal interaction molecule 1) in the membrane of intracellular $\mathrm{Ca}^{2+}$ stores and Orail $\mathrm{Ca}^{2+}$ channels in the plasma membrane. Upon $\mathrm{Ca}^{2+}$ release from intracellular $\mathrm{Ca}^{2+}$ stores, $\mathrm{Ca}^{2+}$ dissociates from a luminal EF hand motif of STIM1. Consequently, STIM1 proteins cluster and recruit Orail $\mathrm{Ca}^{2+}$ channels, which subsequently mediate SOCE $[7,8]$. STIM/Orai- 
mediated $\mathrm{Ca}^{2+}$ signaling contributes to cell migration in different types of cancer, including melanoma [9, 10], glioblastoma [11, 12], renal carcinoma [13], hepatocarcinoma [14], breast cancer $[15,16]$, cervical cancer [17], and prostate cancer [18].

Transient receptor potential melastatin 4 channel (TRPM4) is a monovalent non-selective cation channel that is activated upon elevation of intracellular $\mathrm{Ca}^{2+}[19$, 20]. TRPM4 initiates an important feedback mechanism for intracellular $\mathrm{Ca}^{2+}$ signals, as $\mathrm{Na}^{+}$influx via TRPM4 can depolarize the plasma membrane potential and thus reduce the driving force for $\mathrm{Ca}^{2+}$ influx $[19,21]$. TRPM4 contributes functionally to the pathophysiology of several cardiac diseases [22-33], migration of immune and vascular endothelial cells [34-36], and proliferation of breast cancer cells [37]. TRPM4 is expressed throughout various tissues, and expression levels are most pronounced in the colon and prostate [19, 20]. TRPM4 was significantly elevated in cancer samples in seven of nine studies that compared TRPM4 mRNA expression levels in normal prostate gland and prostate tumor tissue ( $p \leq$ 0.01; www.oncomine.org, all nine studies are summarized in [38]). Another study found increased levels of TRPM4 mRNA when human prostatic intraepithelial neoplasia (PIN; abnormal but somewhat premalignant cells) develop into prostate cancer cells [39]. A recent publication by Schinke and colleagues demonstrated elevated levels of TRPM4 in androgen-insensitive prostate cancer cells and suggested a role for TRPM4 as a cancer driver gene [38].

Thus far, the role of TRPM4 in prostate cancer has been unclear. In the present study, we investigated TRPM4 protein levels in human prostate tissue scored with the Gleason grading system. We also functionally characterized TRPM4 in primary human prostate epithelial cells (hPEC) and in androgen-sensitive (LNCaP) and androgen-insensitive (DU145 and PC3) prostate cancer cell lines. Finally, we determined the potential of TRPM4 to limit SOCE and the functional role of TRPM4 in cell migration and proliferation of prostate cancer cells.

\section{RESULTS}

\section{Elevated TRPM4 expression in PIN and prostate cancer cells}

Prostate tissue samples contain different cell types, including fibroblasts and basal, luminal, and secretory epithelial cells, as well as neuroendocrine cells. Due to this heterogeneous nature, a comparison of the mRNA levels of a gene in cancer versus normal tissue samples is not entirely useful. We thus evaluated TRPM4 antibody staining in paraffin-embedded human prostate cancer tissues from 20 patients (Figure 1, Supplementary Table 1). Figure 1 shows examples of immunohistochemical stainings with TRPM4-specific antibody of prostate cancer tissue samples that were rated with different Gleason scores. We found expression of TRPM4 in hPEC and weak or negligible expression in stromal cells (Figure 1). Areas identified as non-malignant (e.g. Figure 1 panel 1, upper left and panel 2, bottom right) or benign prostatic hyperplasia (BPH) showed no or faint TRPM4 immunoreactivity. In areas of PIN or increased Gleason growth patterns, medium or strong signal intensity of TRPM4 was detected (Figure 1). The specificity of the TRPM4 antibody was verified in consecutive tissue slices ( $\alpha$-TRPM4 and control) and with Western blot analysis upon an siRNA based knockdown of TRPM4 in LNCaP and DU145 cells (SFigure 1A and 1B). Supplementary Table 1 summarizes the clinical characteristics (i.e., classification by Gleason score and tumor nodes metastasis [TNM] stage) of 20 patients with prostate cancer. For these patients, TRPM4 signal intensities were evaluated in areas of tumor, PIN, and BPH. We did not observe any correlation between TRPM4 staining and the clinical or pathological stages of prostate cancer. In all tissue samples, we detected strong TRPM4 staining in malignant and PIN areas and weak or absent staining in areas with $\mathrm{BPH}$.

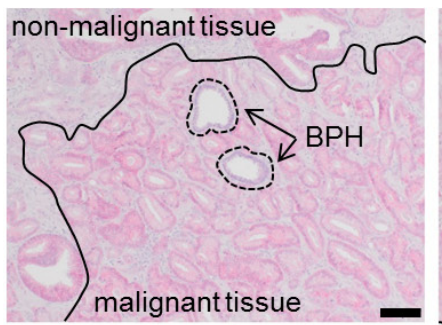

GI. Area 3+BPH

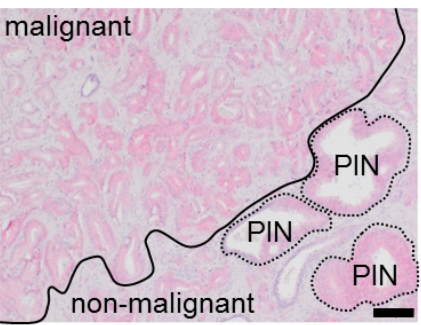

GI. Area 3+PIN

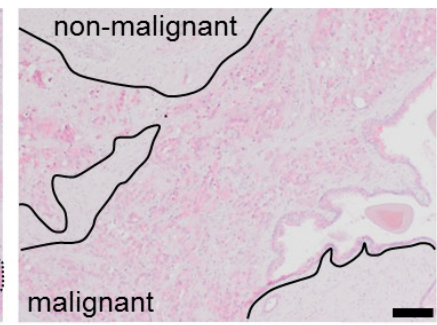

GI. Area 4

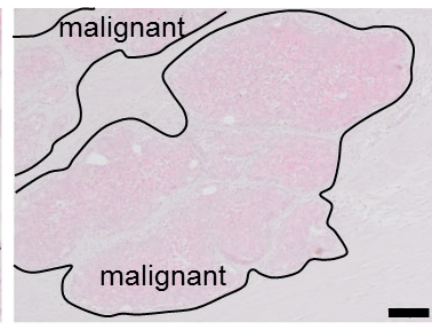

GI. Area 5

Figure 1: Immunohistochemical detection of TRPM4 in prostate cancer tissue. Representative images (original magnification, $100 \times$ ) of TRPM4-immunostained tissue sections from prostate carcinomas are shown. Red staining indicates TRPM4-positive areas. Scale bars represent $100 \mu \mathrm{m}$. 


\section{In hPEC, TRPM4 generates large $\mathrm{Na}^{+}$currents and limits SOCE}

TRPM4 plays a role in several physiological functions such as membrane depolarization, cell death, migration and proliferation [26, 40]. To functionally determine $\mathrm{Na}^{+}$currents via TRPM4 in hPEC, we performed whole-cell patch clamp analysis and evoked TRPM4 currents with 0.1-15 $\mu \mathrm{M}$ free $\mathrm{Ca}^{2+}$ in the patch pipette. Intracellular $\mathrm{Ca}^{2+}$ activated TRPM4 currents in hPEC in a dose-dependent manner (Figure 2A; current-voltage curves [IV] are shown in Figure 2B). For further analysis, we corrected for current not specific to TRPM4, which can also be activated by intracellular $\mathrm{Ca}^{2+}$ e.g. $\mathrm{Ca}^{2+}$ activated $\mathrm{Cl}^{-}$channels [41]. To do so, after current development (400 s), $\mathrm{Na}^{+}$in the external bath solution was replaced by NMDG, a nonpermeable cation. This abolishes all $\mathrm{Na}^{+}$ inward current, and the net $\mathrm{Na}^{+}$current density $(\triangle \mathrm{CD})$ can be analyzed by subtracting NMDG currents (at $406 \mathrm{~s}$ ) from currents in $\mathrm{Na}^{+}$(at $396 \mathrm{~s}$ ). An example of calculating $\Delta \mathrm{CD}$ during analysis of a typical cell is shown in Figure 2C, and the corresponding IV are shown in Figure 2D. $10 \mu \mathrm{M}$ $\mathrm{Ca}^{2+}$ evoked maximal $\triangle \mathrm{CD}$ and we calculated an $\mathrm{EC}_{50}$ for $\mathrm{Ca}^{2+}$-dependent TRPM4 activation of $1.7 \pm 0.2 \mu \mathrm{M}$, which is consistent with published $\mathrm{EC}_{50}$ values of 0.4-9.8 $\mu \mathrm{M}$ [19, 42-44] (Figure 2E). In an siRNA-based knockdown, we found a significant reduction in TRPM4 currents 72 $\mathrm{h}$ after transfection (Figure 2F). Relative gene expression levels of TRPM4 normalized to TATA box binding protein
(TBP) were reduced $72 \mathrm{~h}$ after knockdown, as shown by RT-PCR (Supplementary Figure 1C). Taken together, these experiments demonstrate that increasing intracellular $\mathrm{Ca}^{2+}$ concentrations generate large TRPM4-mediated $\mathrm{Na}^{+}$ currents (up to approximately $70 \mathrm{pA} / \mathrm{pF}$ ) in hPEC.

In a fluorescence-based Fura- $2 \mathrm{Ca}^{2+}$ assay, we tested the potential of TRPM4 to reduce SOCE in hPEC (Figure $3 \mathrm{~A}$ ), as a large $\mathrm{Na}^{+}$influx can lower the driving force for $\mathrm{Ca}^{2+}$. Upon addition of thapsigargin (Tg), an inhibitor of sarcoplasmic/endoplasmic reticulum $\mathrm{Ca}^{2+}$ ATPase (SERCA), intracellular $\mathrm{Ca}^{2+}$ stores were depleted. The $\mathrm{Ca}^{2+}$ release from intracellular $\mathrm{Ca}^{2+}$ stores was detected as a small increase in intracellular $\mathrm{Ca}^{2+}(400-600 \mathrm{~s})$. Upon readdition of extracellular $\mathrm{Ca}^{2+}$ (time $>1000 \mathrm{~s}$ ), SOCE was recorded as described previously [45]. After TRPM4 knockdown, we detected elevated SOCE in hPEC (Figure 3A). The significant increase in rate, peak, and plateau of SOCE after knockdown demonstrates a clear role for TRPM4 in limiting SOCE signals in hPEC (Figure 3B).

\section{TRPM4 generates large $\mathrm{Na}^{+}$currents in prostate cancer cells and limits SOCE in DU145}

We compared TRPM4 activity in hPEC, as well as in the prostate cancer cell lines LNCaP, DU145 and PC3. TRPM4 currents were activated with $10 \mu \mathrm{M}$ intracellular $\mathrm{Ca}^{2+}$, and in case of the $\mathrm{PC} 3$ cells $25 \mu \mathrm{M} \mathrm{Ca}^{2+}$ were used in addition (Figure 4A and 4B, IV are shown in Figure 4C). TRPM4-nonspecific currents were subtracted as described
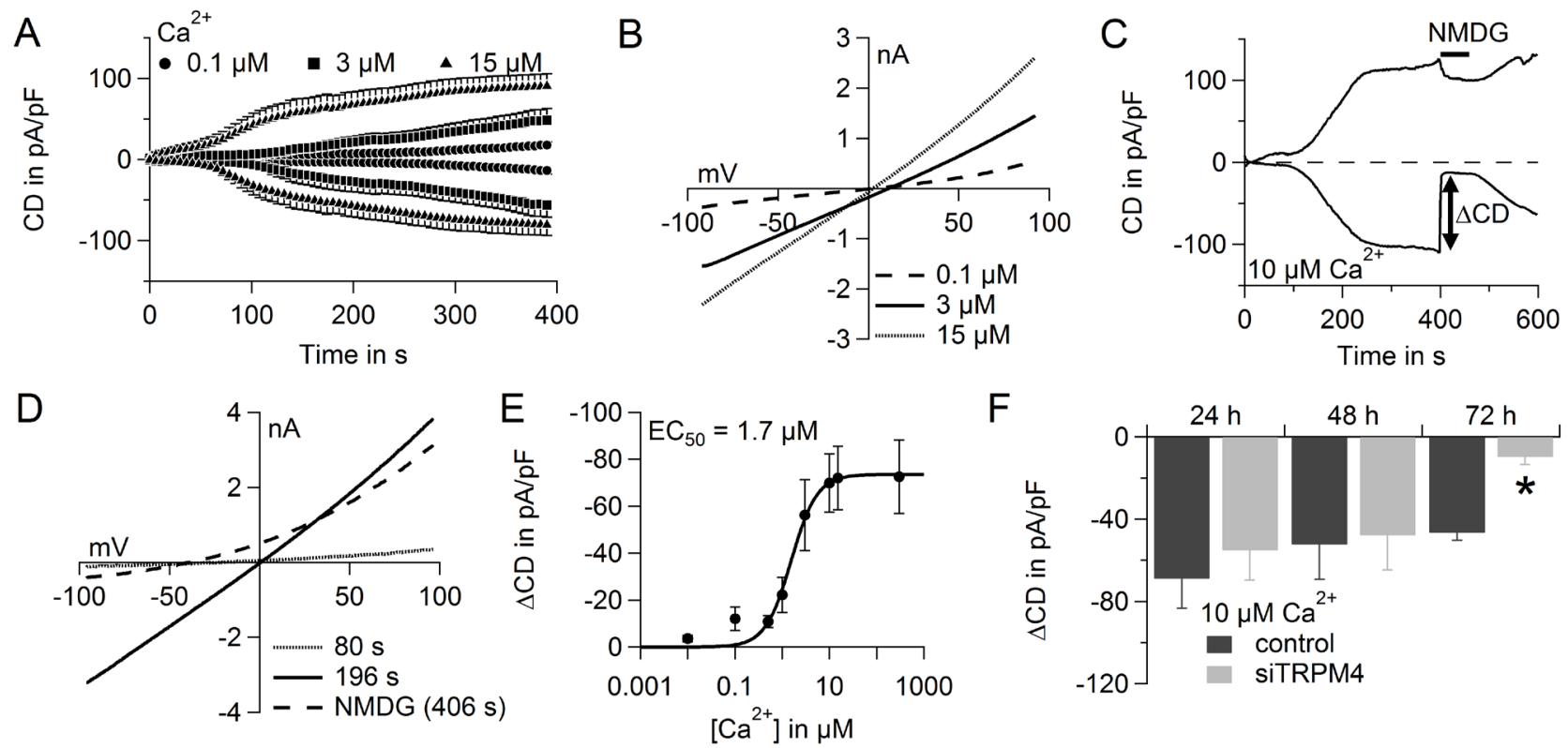

Figure 2: TRPM4 currents in hPEC. A. Time course of averaged TRPM4 current densities (CD) evoked by adjusted intracellular $\mathrm{Ca}^{2+}$ concentrations as indicated $\left(100 \mathrm{nM} \mathrm{Ca}^{2+}, n=7 ; 3 \mu \mathrm{M} \mathrm{Ca}^{2+}, n=12\right.$; and $\left.15 \mu \mathrm{M} \mathrm{Ca}^{2+}, n=11\right)$. B. Average IV for cells in $\mathbf{A}$. at time $=$ 396 s. C. TRPM4 current over time in a typical cell when NMDG was applied as indicated. D. IV for the typical cell in C. at indicated time points. E. Dose-response curve for TRPM4 currents induced with various $\mathrm{Ca}^{2+}$ concentrations: $10 \mathrm{nM} \mathrm{Ca}^{2+}, n=8 ; 500 \mathrm{nM} \mathrm{Ca}^{2+}, n=6 ; 1$ $\mu \mathrm{M} \mathrm{Ca}^{2+}, n=8 ; 10 \mu \mathrm{M} \mathrm{Ca}^{2+}, n=10$; and $300 \mu \mathrm{M} \mathrm{Ca}^{2+}, n=7$. Same cells as in A. for $100 \mathrm{nM}, 3 \mu \mathrm{M}$, and $15 \mu \mathrm{M} \mathrm{Ca}^{2+}$. $\mathrm{EC}_{50}$ for Ca ${ }^{2+}$ was $_{1.7}$ $\mu \mathrm{M}$. F. $\Delta$ Current density $(\triangle \mathrm{CD})$ of TRPM4 current $24 \mathrm{~h}, 48 \mathrm{~h}$, and $72 \mathrm{~h}$ after siRNA-based knockdown of TRPM4 (light grey bars: $24 \mathrm{~h}, n$ $=7 ; 48 \mathrm{~h}, n=9$; and $72 \mathrm{~h}, n=11$ ) and control RNA treatment (dark grey bars: $24 \mathrm{~h}, n=5 ; 48 \mathrm{~h}, n=5$; and $72 \mathrm{~h}, n=9$ ). 
above. Whereas in hPEC TRPM4 exhibited currents of 70 $\pm 13 \mathrm{pA} / \mathrm{pF}$, in the prostate cancer cell lines, the TRPM4 current size was $35 \pm 12 \mathrm{pA} / \mathrm{pF}$ in LNCaP, $59 \pm 17 \mathrm{pA} /$ $\mathrm{pF}$ in DU145, $9 \pm 5 \mathrm{pA} / \mathrm{pF}$ in PC3 cells for $10 \mu \mathrm{M} \mathrm{Ca}^{2+}$ and $56 \pm 11 \mathrm{pA} / \mathrm{pF}$ in PC3 cells for $25 \mu \mathrm{M} \mathrm{Ca}^{2+}$ (Figure 4B). The corresponding IV are shown in Supplementary Figure 2A-2C. While in hPEC $10 \mu \mathrm{M}$ intracellular $\mathrm{Ca}^{2+}$ evoked maximal current (Figure 2E), current development in cancer cells is slower and can be further enlarged with increasing intracellular $\mathrm{Ca}^{2+}$ concentrations as has been demonstrated here for PC3 cells (Figure 4A and 4B).

siRNA-based knockdown of TRPM4 significantly reduced the current size in LNCaP (Figure 4D; IV are shown in Supplementary Figure 3A) and DU145 (Figure
4E; IV are shown in Supplementary Figure 3B), and reduced current size in PC3 (Figure 4F; IV are shown in Supplementary Figure 3C) demonstrating the TRPM4specificity of the detected currents in prostate cancer cells. Knockdown efficiency after $72 \mathrm{~h}$ was determined by RT-PCR, as shown in Supplementary Figure 4A-4C. We also controlled for off-target effects of the TRPM4 specific siRNA within the SOCE pathway and found that expression levels of Orai1, Orai2, Orai3, STIM1 and STIM2 remain largely unchanged (Supplementary Figure 4D and 4E).

As in human prostate cancer tissue TRPM4 was up-regulated (Figure 1); in native cancer cells, TRPM4 currents might well exceed TRPM4 currents in hPEC,
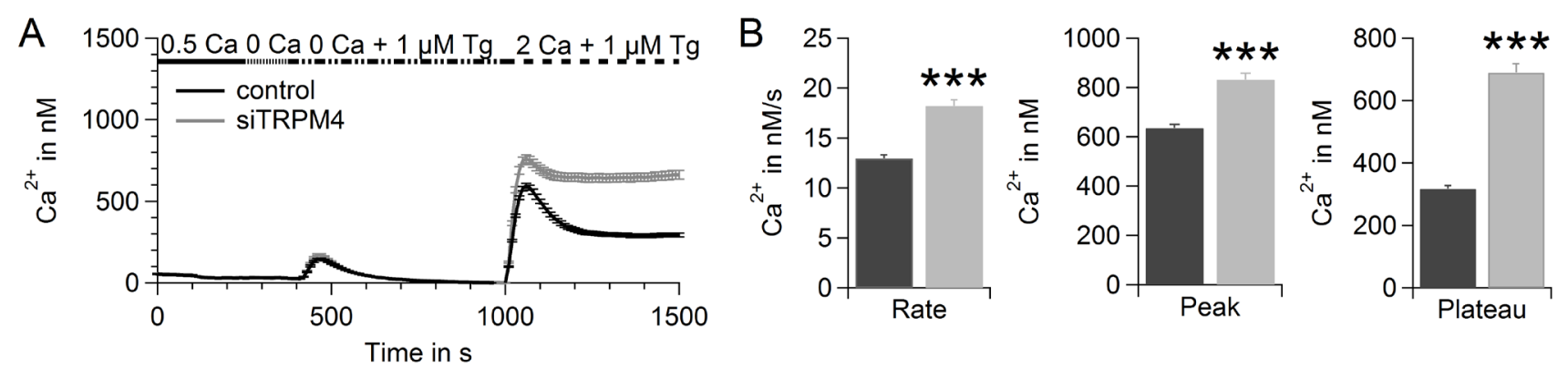

Figure 3: TRPM4 limits SOCE in hPEC. A. Thapsigargin-induced SOCE in hPEC transfected with control RNA (black, $n=338$; two donors) or TRPM4 siRNA (grey, $n=265$; two donors) $72 \mathrm{~h}$ after transfection measured in a Fura-2-based $\mathrm{Ca}^{2+}$ readdition protocol. B. Analysis of the rate, peak, and plateau of $\mathrm{Ca}^{2+}$ entry of cells shown in $\mathbf{A}$.
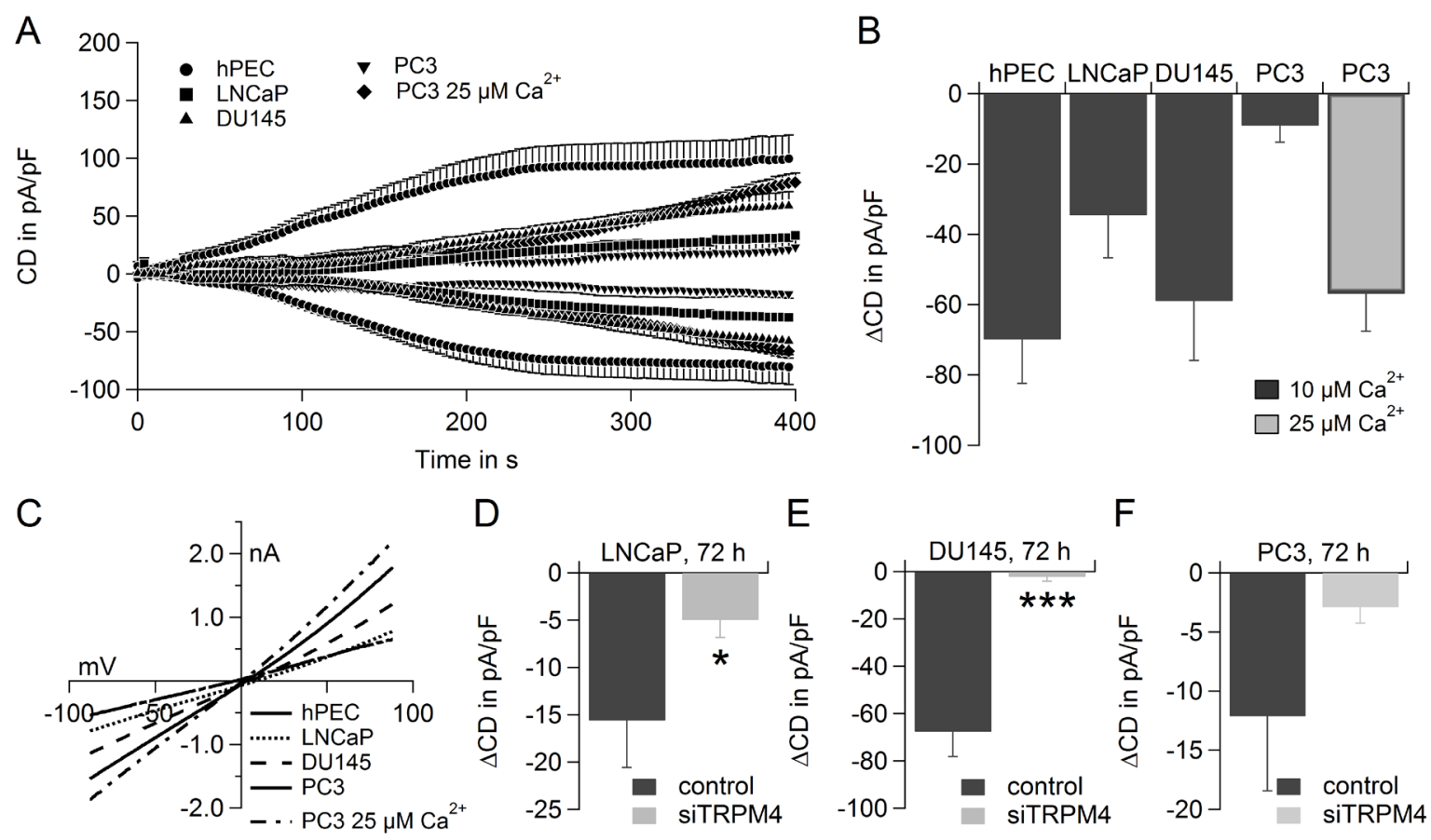

Figure 4: TRPM4 currents in hPEC, LNCaP, DU145 and PC3. A. Time course of averaged TRPM4 current densities (CD) in hPEC, LNCaP, DU145 and PC3 evoked by $10 \mu \mathrm{M} \mathrm{Ca}^{2+}$ if not indicated otherwise, hPEC $(n=10$, same cells as in $\mathbf{2 E}$., LNCaP $(n=10)$, DU145 $(n=7)$ and PC3 $\left(n=6\right.$ for $10 \mu \mathrm{M} \mathrm{Ca}^{2+}$ and $n=5$ for $\left.25 \mu \mathrm{M} \mathrm{Ca}^{2+}\right)$. B. $\Delta$ CD from cells in A.. C. IV at $\mathrm{t}=396 \mathrm{~s}$ for cells in A.. D. $\Delta$ CD evoked with $10 \mu \mathrm{M} \mathrm{Ca}^{2+}$ in the patch pipette in LNCaP cells transfected with control RNA (dark grey bar, $n=5$ ) or siRNA to down-regulate TRPM4 (light grey bar, $n=6$ ). E. $\Delta \mathrm{CD}$ evoked with $10 \mu \mathrm{M} \mathrm{Ca}^{2+}$ in the patch pipette in DU145 cells transfected with control RNA (dark grey bar, $n=5$ ) or siRNA to down-regulate TRPM4 (light grey bar, $n=7$ ). F. $\Delta$ CD evoked with $10 \mu \mathrm{M} \mathrm{Ca}^{2+}$ in the patch pipette in PC 3 cells transfected with control RNA (dark grey bar, $n=5$ ) or siRNA to down-regulate TRPM4 (light grey bar, $n=5$ ). 
even though under the conditions used here TRPM4 currents in cancer cell lines were lower than in hPEC.

To further delineate the role of TRPM4 in prostate cancer, we investigated the potential of TRPM4 to limit $\mathrm{Ca}^{2+}$ signals in the prostate cancer cell lines DU145 and PC3. We performed the same Fura- 2 based $\mathrm{Ca}^{2+}$ assay as in Figure 3A for DU145 (Figure 5A). In DU145 cells, knockdown of TRPM4 significantly increased the rate, peak, and plateau of SOCE (Figure 5A and 5B). When the membrane potential is clamped close to $0 \mathrm{mV}$ (high $\mathrm{K}^{+}$Ringer), knockdown of TRPM4 only slightly increase the peak of SOCE while the $\mathrm{Ca}^{2+}$ entry rate and plateau of SOCE remained unchanged (SFigure 5A). Under these conditions the relative increase in SOCE upon knockdown of TRPM4 is significantly reduced for the $\mathrm{Ca}^{2+}$ entry rate and plateau of SOCE (SFigure 5B) compared to standard conditions. We conclude that upon activation of TRPM4 the concomitant $\mathrm{Na}^{+}$influx leads to a depolarization of the membrane potential. Thus the driving force for $\mathrm{Ca}^{2+}$ entry is reduced and SOCE is limited. In PC3 cells we did not detect increased SOCE upon knockdown of TRPM4 (SFigure 6).

Both, DU145 and PC3 cells exhibit large TRPM4 currents and in addition TRPM4 significantly reduced SOCE in DU145 cells. Thus, we investigate the function of TRPM4 in androgen-insensitive prostate cancer cells DU145 and PC3.
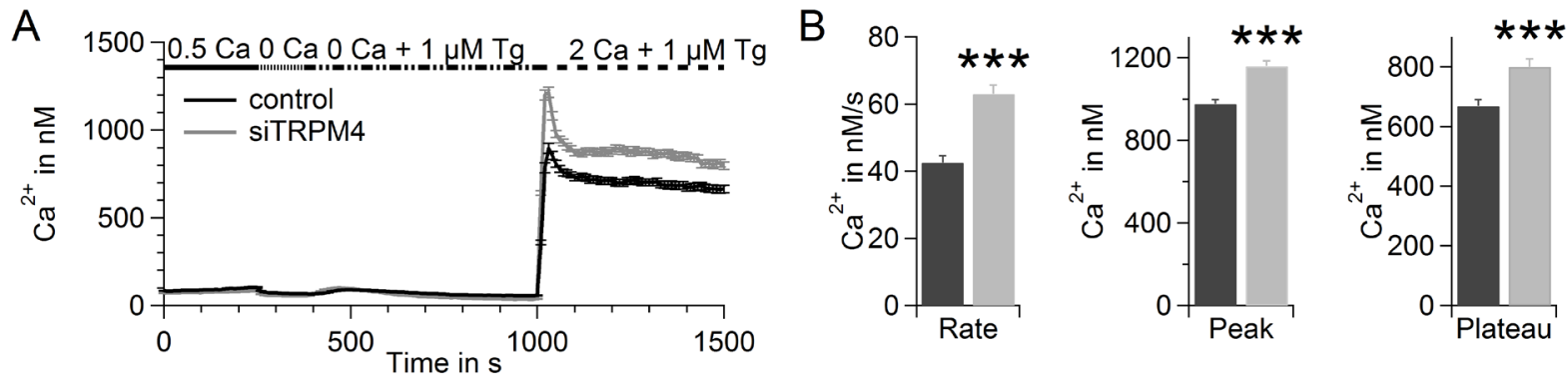

Figure 5: TRPM4 limits SOCE in in DU145. A. Thapsigargin-induced SOCE in DU145 transfected with control RNA (black, $n=$ 338) or TRPM4 siRNA (grey, $n=215$ ) measured during a $\mathrm{Ca}^{2+}$-readdition protocol $72 \mathrm{~h}$ after transfection. B. Analysis of the rate, peak, and plateau of $\mathrm{Ca}^{2+}$ entry of cells shown in $\mathbf{A}$.

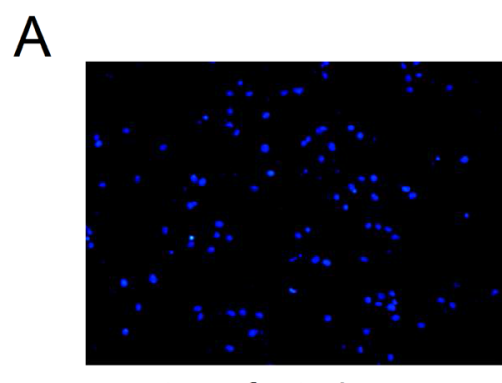

non-transfected

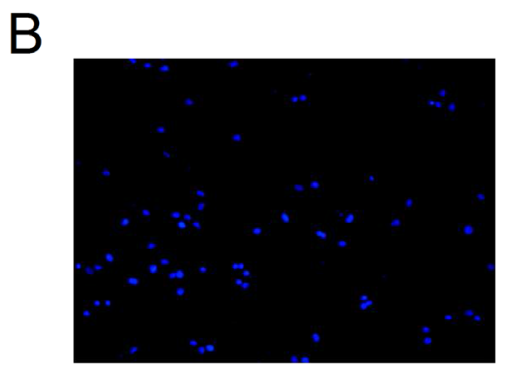

control transfected

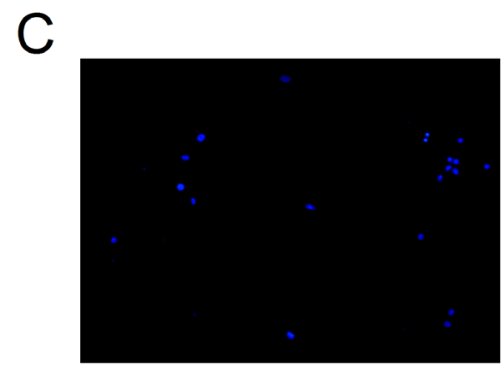

SiRNA TRPM4
D

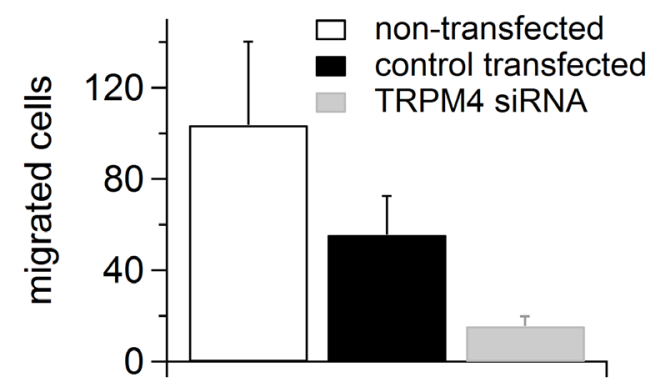

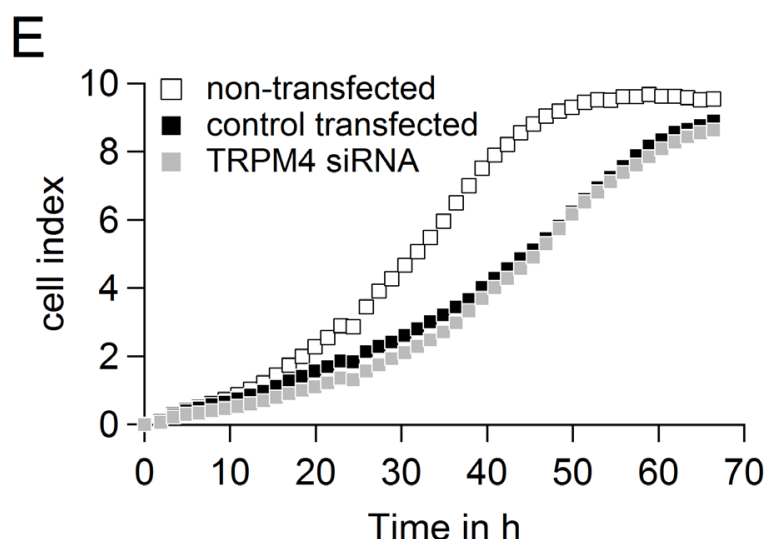

Figure 6: Down-regulation of TRPM4 leads to reduced migration potential of DU145 cells. A.-C. Migrated cells when DU145 cells were either not transfected A. or transfected with control RNA B. or siRNA against TRPM4 C.. D. Analysis of migration of cells in (A.-C.). E. Proliferation of cells in (A.-C.). 


\section{TRPM4 in migration and proliferation}

We tested the migration of DU145 and PC3 cells when cells were either non-transfected or transfected with control RNA or siRNA targeting TRPM4 (Figure 6A$6 \mathrm{D}$ and 7A-7D). Although transfection had a clear effect on the migration potential of these cells, knockdown of TRPM4 resulted in a strong decrease in migration compared to control transfected cells (Figure 6D and Figure 7D). Figure 6E and 7E show that transfection affected the proliferation of the DU145 and PC3 cells, but there was no difference between TRPM4 siRNAor control RNA-transfected cells. To summarize, the decreased migration of transfected DU145 and PC3 cells upon control transfection can be explained by decreased proliferation, but knockdown of TRPM4 also specifically reduces the migration of DU145 and PC 3 cells.

\section{DISCUSSION}

Cell migration depends on intracellular $\mathrm{Ca}^{2+}$ and lately the spatial and temporal organisation of STIM/ Orai dependent $\mathrm{Ca}^{2+}$ gradients has been revealed [4648]. In addition to SOCE channels, several TRP channels contribute to the migration of cancer cells, including TRP channels TRPC1, TRPM7, TRPM8, TRPV1, TRPV2, and TRPV6 [3]. TRPM4 is known to generate an important feedback mechanism for SOCE and to contribute to the migration of dendritic cells, mast cells and vascular endothelial cells [19, 21, 34-36, 49].

We demonstrated that TRPM4 protein levels in areas of PIN and human prostate cancer tissues rated with different Gleason scores were elevated compared to TRPM4 expression in healthy tissue or areas of $\mathrm{BPH}$. These findings are in line with several studies that demonstrate increased levels of TRPM4 mRNA in prostate cancer samples compared to healthy tissues (summarized in [38]).

TRPM4 conducted large $\mathrm{Na}^{+}$currents in both, hPEC and in prostate cancer cell lines. We here investigated the role of TRPM4 in prostate cancer cells that - in contrast to hPEC - are characterized by several pathophysiological changes in cellular functions such as unlimited proliferation and enhanced migration potential. Even though the current in DU145 and PC3 cells may be lower than in native cancer cells, here, DU145 and PC3 serve as model cell lines to investigate the function of TRPM4 in androgen-insensitive prostate cancer. In both prostate cancer cell lines knockdown of TPRM4 reduced migration while proliferation remained unaffected.

In DU145 cells activation of TRPM4 depolarizes the membrane potential, reduces the driving force for $\mathrm{Ca}^{2+}$ and is thus an important negative feedback regulator of SOCE. While TRPM4 regulates SOCE in DU145 cells we could not detect a regulatory role for TRPM4 on $\mathrm{Ca}^{2+}$

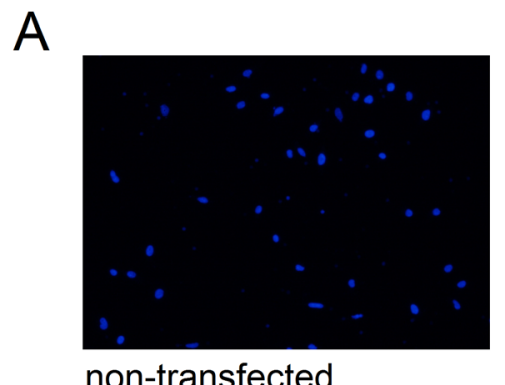

non-transfected

B

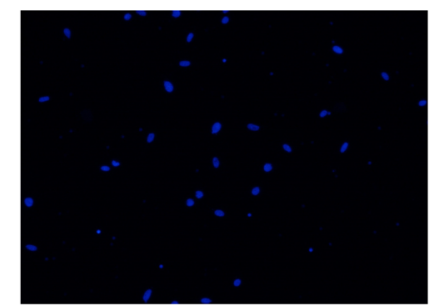

control transfected

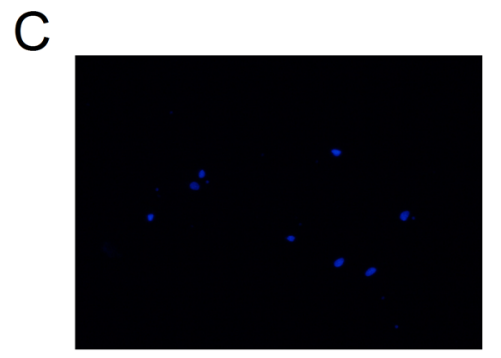

siRNA TRPM4
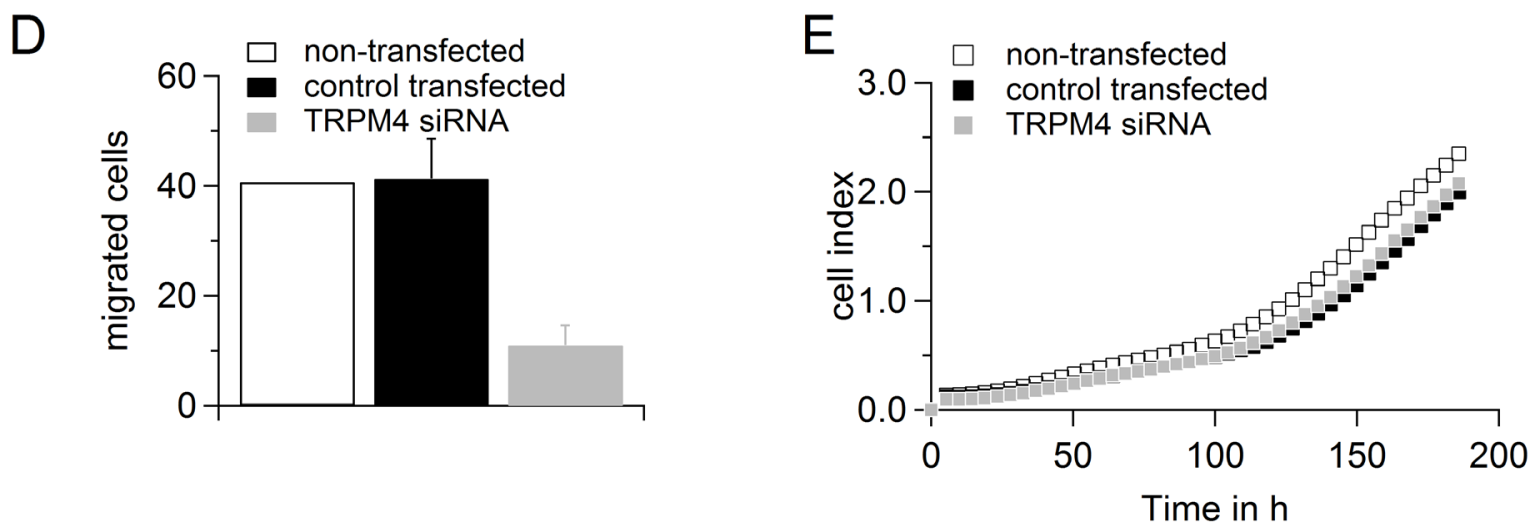

Figure 7: Down-regulation of TRPM4 leads to reduced migration potential of PC3 cells. A.-C. Migrated cells when PC3 cells were either not transfected A. or transfected with control RNA B. or siRNA against TRPM4C.. D. Analysis of migration of cells in (A.-C.). E. Proliferation of cells in (A.-C.). 
signaling in PC3 cells, probably due to the slower current activation and/or limitations of our $\mathrm{Ca}^{2+}$ imaging protocol. A very recent study describes TRPM4 as a component of the adhesome required for migration. TRPM4 contributes to cell migration not only by regulating intracellular $\mathrm{Ca}^{2+}$ signaling but also by direct interaction with several proteins involved in actin cytoskeleton dynamics [50]. Thus the regulatory mechanism of TRPM4 on migration of prostate cancer cells may differ in DU145 and PC3 cells and include $\mathrm{Ca}^{2+}$ independent mechanisms.

While Armisen et al. clearly demonstrate a role for TRPM4 in the proliferation of breast cancer cells [37], we cannot detect a TRPM4-specific effect on proliferation of prostate cancer cells. One explanation may be that the transfection of prostate cancer cells itself has a clear impact on their proliferation which may cover any specific contribution of TRPM4. Another explanation could be that TRPM4 regulates proliferation in breast cancer cells while in prostate cancer TRPM4 does not impair proliferation.

Disordered $\mathrm{Ca}^{2+}$ signals in cancer have been investigated for decades, and consequently several therapeutic strategies have been developed to target $\mathrm{Ca}^{2+}$-transporting enzymes $[4,6]$. Currently, the prostatetargeted thapsigargin derivative mipsagargin is being tested in a phase II clinical trial [51]. Advanced strategies based on calmodulin antagonists that further sensitize prostate cancer cells to thapsigargin therapies have delivered promising results [52].

Down-regulation of TRPM4 strongly decreased cell migration of DU145 and PC3 cells, suggesting a role for TRPM4 in prostate cancer invasion - the initial step for tumor metastasis. We suggest that up-regulation of the TRPM4 cancer driver gene [38] functionally contributes to the development of PIN and prostate cancer by elevating the migration potential of androgen-insensitive prostate cancer cells. TRPM4 contributes to the migration of prostate cancer cells and is thus an interesting potential pharmacological target. The ubiquitous expression pattern of TRPM4 implies a versatile role for TRPM4 in cancer cell migration.

\section{MATERIALS AND METHODS}

\section{Immunohistochemistry}

This study was approved by the local ethical review board and was performed in accordance with the Declaration of Helsinki. After we received written informed consent, prostate cancer tissues from 20 patients were obtained after radical prostatectomy from thus far untreated prostate cancer patients. Gleason score, pathologic stage, histologic diagnosis, and tumor node metastasis classification (TNM) were done in accordance with the guidelines of the Union for International
Cancer Control (2002). Tissue samples were cut into $3 \mu \mathrm{m}$ thick sections, transferred onto Superfrost Ultra Plus Microscope Slides (Menzel-Gläser, Braunschweig, Germany), and dried in an incubator at $37^{\circ} \mathrm{C}$ overnight. After deparaffinization, heat-induced epitope retrieval was performed by treatment in $10 \mathrm{mmol} / \mathrm{L}$ citrate buffer $(\mathrm{pH}$ 6.0 ) and nonspecific protein binding sites were blocked by incubation in blocking solution $(80 \mathrm{~mL}$ of $0.1 \mathrm{M}$ Tris- $\mathrm{HCl}$ $\mathrm{pH}$ 7.2, $3 \mathrm{~g}$ of bovine serum albumin [BSA; Sigma Aldrich, Germany], and $20 \mathrm{~mL}$ of fetal bovine serum [FBS; Sigma Aldrich Chemie $\mathrm{GmbH}$ ]) for $30 \mathrm{~min}$ at room temperature. Subsequently, primary antibody incubation was performed with a $1: 100$ solution (diluted in phosphate-buffered saline/0.3\% BSA) of a specific TRPM4 monoclonal mouse antibody ([53] Clone 10H5, TA500381; Origene, Rockville, MD, USA) overnight at $4^{\circ} \mathrm{C}$. Each staining series included negative controls without $\alpha$-TRPM4 incubation. Visualization was performed with the DAKO Real Detection System (DAKO, Glostrup, Denmark) in accordance with the manufacturer's instructions, and slides were counterstained with hematoxylin. TRPM4 staining intensity was classified as no staining (0), weak $(+)$, intermediate $(++)$, or strong $(+++)$.

\section{Cell culture and prostate tissue collection}

Lymph node carcinoma of the prostate ( $\mathrm{LNCaP}$ ) cells, DU145 and PC3 were purchased from the American Type Cell Culture Collection (ATCC, Rockville, MD, USA) and cultured in RPMI Medium 1640 (Life Technologies) supplemented with $10 \%$ FCS and $1 \%$ penicillin/streptomycin (Life Technologies). Prostate tissue was obtained from prostectomy specimens (ethics approval 168/05, Ärztekammer des Saarlandes), and hPEC were isolated, with slight modifications, in accordance with [54], as described in [45].

\section{Western blot analysis}

For Western blot analysis, cells were lysed and 200 $\mu \mathrm{g}$ of total protein was separated by $10 \%$ SDS-PAGE. Immunoblots were probed with anti-TRPM4 antibody (1:250; Origene). The manusfacturer's control was used to test for positive TRPM4 staining. Antibodies and proteins were detected with an enhanced chemiluminescence detection system (ECL; Biorad).

\section{Quantitative real-time PCR (qRT-PCR)}

Total RNA from LNCaP, DU145, PC3 and hPEC was isolated with TRIzol Reagent (Life Technologies) and from prostate tissue with the RNeasy Mini kit (Qiagen). For reverse transcription, $0.8 \mu \mathrm{g}$ of isolated total RNA was used. Complementary DNA (cDNA; 0.5 
$\mu \mathrm{l})$ and $300 \mathrm{nM}$ primer were used with a QuantiTect SYBRgreen kit (Qiagen). PCR conditions were as follows: $15 \mathrm{~min}$ at $95^{\circ} \mathrm{C} ; 45$ cycles of $30 \mathrm{~s}$ at $95^{\circ} \mathrm{C}, 45 \mathrm{~s}$ at $58^{\circ} \mathrm{C}$, and $30 \mathrm{~s}$ at $72^{\circ} \mathrm{C}$; and finally a cycle $\left(60 \mathrm{~s}\right.$ at $95^{\circ} \mathrm{C}, 30$ $\mathrm{s}$ at $55^{\circ} \mathrm{C}$, and $30 \mathrm{~s}$ at $95^{\circ} \mathrm{C}$ ) to determine specificity by a dissociation curve using the MX3000 cycler (Stratagene). Expression of target genes was normalized to expression of the reference genes RNA polymerase II (RNAPol, NM_000937) and/or TATA box binding protein (TBP, NM_003194). Primer sequences for TRPM4 (NM 017636) were 5'-gtatctgctctcggacaag-3' (forward)

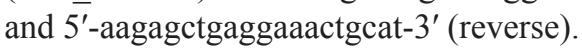

\section{$\mathrm{Ca}^{2+}$ imaging}

$\mathrm{Ca}^{2+}$ imaging experiments were performed in accordance with [55]. Cells were cultured overnight on glass cover slips and loaded with $1 \mu \mathrm{M}$ Fura-2/ $\mathrm{AM}$ at $37^{\circ} \mathrm{C}$ for $20 \mathrm{~min}$. Glass coverslips were placed in a perfusion chamber in a Zeiss Axio Observer.A1 fluorescence microscope equipped with a "Plan-Neofluar" $20 \times / 0.4$ objective (Zeiss). The excitation light, generated by a Polychrome $V$ in a TILL Photonics real-time imaging system, alternated at 340 and $380 \mathrm{~nm}$, and the exposure time was set to $50 \mathrm{~ms}$ in each channel. Light intensity at emission wavelength $440 \mathrm{~nm}$ was detected every $5 \mathrm{~s}$ and digitized by a charge-coupled device camera (Q-Imaging Retiga 2000RV). Bath solution contained (in $\mathrm{mM}$ ): 155 $\mathrm{NaCl}, 4.5 \mathrm{KCl}, 2 \mathrm{MgCl}_{2}, 10 \mathrm{D}$-glucose, and 5 Hepes (pH 7.4 with $\mathrm{NaOH}$ ). $\mathrm{CaCl}_{2}$ and thapsigargin in the bath solution was adjusted as indicated. Stock solutions of thapsigargin were prepared in DMSO at a concentration of $1 \mathrm{mM}$. In the experiment in SFigure 5 the bath solution contained (in mM): $155 \mathrm{KCl}, 2 \mathrm{MgCl}_{2}, 10 \mathrm{D}$-glucose, and 5 Hepes (pH 7.4 with $\mathrm{NaOH}$ ).

\section{Electrophysiology}

Cells were patched in a tight-seal whole-cell configuration as described in $[56,57]$. Every $2 \mathrm{~s}$, voltage ramps of $50 \mathrm{~ms}$ duration from a holding potential of 0 $\mathrm{mV}$, spanning $-100 \mathrm{mV}$ to $+100 \mathrm{mV}$, were delivered by a Patchmaster software-controlled EPC-10 patch-clamp amplifier (HEKA). Before each voltage ramp, capacitive currents were determined and corrected. Data were filtered at $1 \mathrm{kHz}$ and sample rate was $3 \mathrm{kHz}$, and the liquid junction potential was corrected $(-10 \mathrm{mV})$. For analysis, currents were extracted at $-80 \mathrm{mV}$ and $80 \mathrm{mV}$, normalized to the cell capacity, and plotted versus time. Bath solutions contained (in mM): $140 \mathrm{NaCl}, 0.5 \mathrm{CaCl}_{2}, 3 \mathrm{MgCl}_{2}, 10$ HEPES, and 30 glucose. $\mathrm{pH}$ was adjusted with $\mathrm{NaOH}$ to 7.2 , and osmolarity was $330 \mathrm{mOsmol} / \mathrm{L}$. In the N-methyld-glucamine (NMDG) bath solution, $140 \mathrm{mM} \mathrm{NaCl}$ was replaced by $140 \mathrm{mM}$ NMDG. Pipette solution contained (in $\mathrm{mM}$ ): 140 Cs glutamate, 10 HEDTA, 10 HEPES, 8
$\mathrm{NaCl}, \mathrm{MgCl}_{2}$ and $\mathrm{CaCl}_{2} \cdot \mathrm{MgCl}_{2}$ and $\mathrm{CaCl}_{2}$ were calculated (http://www.stanford.edu/wcpatton/webmaxcS.htm) and added to reach an end concentration for free $\mathrm{Mg}^{2+}$ of 3 $\mathrm{mM}$ and free $\mathrm{Ca}^{2+}$ as indicated.

\section{Data analysis and statistics}

Data are given as means \pm standard error of the mean (SEM) and were analyzed with TILLVision (TILL Photonics), Fitmaster 2.35 (HEKA), Igor Pro (Wavemetrics), and Microsoft Excel (Microsoft). Asterisks indicate significance and were determined by unpaired, two-sided Student's $t$-test: *, $p<0.05$; **, $p<0.01$; and $* * *, p<0.001$. Half maximal effective concentration $\left(\mathrm{EC}_{50}\right)$ was determined by a fit with Hill's equations (leastsquares method). For $\mathrm{Ca}^{2+}$ imaging, intracellular $\mathrm{Ca}^{2+}$ concentration was calculated from the equation $\left[\mathrm{Ca}^{2+}\right]_{\mathrm{i}}=$ $\mathrm{K}\left(\mathrm{R}-\mathrm{R}_{\min }\right) /\left(\mathrm{R}_{\max }-\mathrm{R}\right)$, in which $\mathrm{K}, \mathrm{R}, \mathrm{R}_{\text {min }}$, and $\mathrm{R}_{\text {max }}$ were determined in the corresponding in situ calibration for hPEC, LNCaP, and DU145 cells, in accordance with [58]. For qRT-PCR, relative expression was calculated with the $\Delta \mathrm{Cq}$ method $\left(2^{-\Delta \mathrm{Cq}}\right)$ and $\mathrm{Cq}$ values were determined with the MX3000.

\section{Small interfering RNA transfection (siRNA)}

TRPM4 siRNAs were 5'-GCACGACGUUC AUAGUUGATT-3' (sense) and 3-'GACGUGCUGCAA GUAUCAACU-5' (antisense) (Qiagen). Non-silencing RNA were MS_control_mod [sense: 5'OmeA-OMeAAGGUAGUGUAAUCGCd(CUU) OMeG-OmeTOMeT3'; antisense: 3'OmeT-OmeTUCCAUCACA UUAGCGGAAdC5']. Nucleofector II (Amaxa Lonza) nucleofector and the Nucleofector Transfection Kit R (Lonza) were used in accordance with the manufacturer's instructions to transfect $0.12 \mathrm{nmol}$ siRNA per transfection.

\section{Migration potential analysis}

Migration was tested with the BD Falcon FluoroBloksystem (BD Biosciences, Franklin Lakes, NJ, USA) in 24-well inserts. A total of $2.5 \times 10^{4}$ DU 145 or PC3 cells treated with control RNA or TRPM4 siRNA were loaded into this system in RPMI-1640 medium containing $1.0 \%$ FBS. The inserts were placed in RPMI1640 medium with $10 \%$ FBS as an attractant. After 48 $\mathrm{h}$, the cells were fixed with methanol and stained with DAPI and migrating cells were analyzed on the backside of the membrane by fluorescence. The experiment was repeated three times, and the migrated cells of at least three individual images were automatically counted using NIS-Elements AR Software (Nikon). 


\section{Real-time cell proliferation analysis}

The xCELLigence SP system (Roche Diagnostics $\mathrm{GmbH}$, Mannheim, Germany) was used for real-time analysis of cell proliferation. In this system, $5.0 \times$ $10^{3}$ DU145 cells or PC3 cells, either untransfected or transfected with control RNA or TRPM4 siRNA, were seeded into a 96-well E-plate (Roche Diagnostics $\mathrm{GmbH}$ ) in accordance with the manufacturer's instructions. Cells pretreated with siRNA were seeded $72 \mathrm{~h}$ after transfection. Cell proliferation was monitored for $96 \mathrm{~h}$, and data were evaluated with RTCA 2.0 software (Roche Diagnostics $\mathrm{GmbH})$.

\section{ACKNOWLEDGMENTS}

We thank Helga Angeli, Andrea Armbrüster, Petra Frie $\beta$, Cora Hoxha, Sandra Janku and Gertrud Schwär for their technical support. CP thanks Andreas Beck for the helpful scientific discussion and Sandra Janku for careful reading of the manuscript. In addition, CP thanks Markus Hoth for constant and exceptional support.

\section{FUNDING}

This work was supported by the Deutsche Forschungsgemeinschaft (SFB 894 [A2] and PE1478/5-1 to CP). VJ acknowledges funding by the Stiftung Europrofession and the Homburger Forschungsförderungsprogramm of Saarland University.

\section{CONFLICTS OF INTERESTS}

The authors have no conflicts of interest to disclose.

\section{REFERENCES}

1. Flourakis M, Lehen'kyi V, Beck B, Raphael M, Vandenberghe M, Abeele FV, Roudbaraki M, Lepage G, Mauroy B, Romanin C, Shuba Y, Skryma R and Prevarskaya N. Orail contributes to the establishment of an apoptosis-resistant phenotype in prostate cancer cells. Cell. Death Dis. 2010; e75.

2. Vanden Abeele F, Skryma R, Shuba Y, Van Coppenolle F, Slomianny C, Roudbaraki M, Mauroy B, Wuytack F and Prevarskaya N. Bcl-2-dependent modulation of $\mathrm{Ca}(2+)$ homeostasis and store-operated channels in prostate cancer cells. Cancer.Cell. 2002; 2: 169-179.

3. Prevarskaya N, Ouadid-Ahidouch H, Skryma R and Shuba Y. Remodelling of Ca2+ transport in cancer: how it contributes to cancer hallmarks? Philos.Trans.R.Soc. Lond.B.Biol.Sci. 2014; 1638: 20130097.

4. Monteith GR, McAndrew D, Faddy HM and RobertsThomson SJ. Calcium and cancer: targeting $\mathrm{Ca} 2+$ transport.
Nat.Rev.Cancer. 2007; 7: 519-530.

5. Pelley RP, Chinnakannu K, Murthy S, Strickland FM, Menon M, Dou QP, Barrack ER and Reddy GP. Calmodulin-androgen receptor (AR) interaction: calciumdependent, calpain-mediated breakdown of AR in LNCaP prostate cancer cells. Cancer Res. 2006; 24: 11754-11762.

6. Prevarskaya N, Skryma R and Shuba Y. Targeting $\mathrm{Ca}(2)(+)$ transport in cancer: close reality or long perspective? Expert Opin.Ther.Targets. 2013; 3: 225-241.

7. Lewis RS. Store-operated calcium channels: new perspectives on mechanism and function. Cold Spring Harb Perspect.Biol. 2011; 12: 10.1101/cshperspect.a003970.

8. Muik M, Schindl R, Fahrner M and Romanin C. $\mathrm{Ca}(2+)$ release-activated $\mathrm{Ca}(2+)$ (CRAC) current, structure, and function. Cell Mol.Life Sci. 2012; 69:4163-76.

9. Stanisz H, Saul S, Muller CS, Kappl R, Niemeyer BA, Vogt $\mathrm{T}$, Hoth M, Roesch A and Bogeski I. Inverse regulation of melanoma growth and migration by Orai1/STIM2dependent calcium entry. Pigment Cell.Melanoma Res. 2014; 27:442-53.

10. Umemura M, Baljinnyam E, Feske S, De Lorenzo MS, Xie LH, Feng X, Oda K, Makino A, Fujita T, Yokoyama U, Iwatsubo M, Chen S, Goydos JS, Ishikawa Y and Iwatsubo K. Store-Operated $\mathrm{Ca}(2)(+)$ Entry (SOCE) Regulates Melanoma Proliferation and Cell Migration. PLoS One. 2014; 2: e89292.

11. Shi ZX, Rao W, Wang H, Wang ND, Si JW, Zhao J, Li JC and Wang ZR. Modeled microgravity suppressed invasion and migration of human glioblastoma U87 cells through downregulating store-operated calcium entry. Biochem. Biophys.Res.Commun. 2015; 3: 378-384.

12. Motiani RK, Hyzinski-Garcia MC, Zhang X, Henkel MM, Abdullaev IF, Kuo YH, Matrougui K, Mongin AA and Trebak M. STIM1 and Orai1 mediate CRAC channel activity and are essential for human glioblastoma invasion. Pflugers Arch. 2013; 9: 1249-1260.

13. Kim JH, Lkhagvadorj S, Lee MR, Hwang KH, Chung HC, Jung JH, Cha SK and Eom M. Orail and STIM1 are critical for cell migration and proliferation of clear cell renal cell carcinoma. Biochem.Biophys.Res.Commun. 2014; 1: 7682.

14. Yang N, Tang Y, Wang F, Zhang H, Xu D, Shen Y, Sun $\mathrm{S}$ and Yang $\mathrm{G}$. Blockade of store-operated $\mathrm{Ca}(2+)$ entry inhibits hepatocarcinoma cell migration and invasion by regulating focal adhesion turnover. Cancer Lett. 2013; 2: 163-169.

15. Yang S, Zhang JJ and Huang XY. Orail and STIM1 are critical for breast tumor cell migration and metastasis. Cancer.Cell. 2009; 2: 124-134.

16. Hammadi M, Chopin V, Matifat F, Dhennin-Duthille I, Chasseraud M, Sevestre H and Ouadid-Ahidouch H. Human ether a-gogo $\mathrm{K}(+)$ channel 1 (hEag1) regulates MDA-MB-231 breast cancer cell migration through Orai1dependent calcium entry. J.Cell.Physiol. 2012; 12: $3837-$ 
3846.

17. Chen YF, Chiu WT, Chen YT, Lin PY, Huang HJ, Chou CY, Chang HC, Tang MJ and Shen MR. Calcium store sensor stromal-interaction molecule 1-dependent signaling plays an important role in cervical cancer growth, migration, and angiogenesis. Proc.Natl.Acad.Sci.U.S.A. 2011; 37: 15225-15230.

18. Derouiche S, Warnier M, Mariot P, Gosset P, Mauroy B, Bonnal JL, Slomianny C, Delcourt P, Prevarskaya N and Roudbaraki M. Bisphenol A stimulates human prostate cancer cell migration via remodelling of calcium signalling. Springerplus. 2013; 1: 54-1801-2-54. Epub 2013 Feb 15.

19. Launay P, Fleig A, Perraud AL, Scharenberg AM, Penner $\mathrm{R}$ and Kinet JP. TRPM4 is a Ca2+-activated nonselective cation channel mediating cell membrane depolarization. Cell. 2002; 3: 397-407.

20. Nilius B, Prenen J, Droogmans G, Voets T, Vennekens R, Freichel M, Wissenbach U and Flockerzi V. Voltage dependence of the Ca2+-activated cation channel TRPM4. J.Biol.Chem. 2003; 33: 30813-30820.

21. Vennekens R, Olausson J, Meissner M, Bloch W, Mathar I, Philipp SE, Schmitz F, Weissgerber P, Nilius B, Flockerzi $\mathrm{V}$ and Freichel M. Increased IgE-dependent mast cell activation and anaphylactic responses in mice lacking the calcium-activated nonselective cation channel TRPM4. Nat. Immunol. 2007; 3: 312-320.

22. Kruse M, Schulze-Bahr E, Corfield V, Beckmann A, Stallmeyer B, Kurtbay G, Ohmert I, Schulze-Bahr E, Brink $\mathrm{P}$ and Pongs $\mathrm{O}$. Impaired endocytosis of the ion channel TRPM4 is associated with human progressive familial heart block type I. J.Clin.Invest. 2009; 9: 2737-2744.

23. Liu H, El Zein L, Kruse M, Guinamard R, Beckmann A, Bozio A, Kurtbay G, Megarbane A, Ohmert I, Blaysat G, Villain E, Pongs $\mathrm{O}$ and Bouvagnet P. Gain-of-function mutations in TRPM4 cause autosomal dominant isolated cardiac conduction disease. Circ.Cardiovasc.Genet. 2010; 4: 374-385.

24. Mathar I, Kecskes M, Van der Mieren G, Jacobs G, Camacho Londono JE, Uhl S, Flockerzi V, Voets T, Freichel M, Nilius B, Herijgers $\mathrm{P}$ and Vennekens $\mathrm{R}$. Increased beta-adrenergic inotropy in ventricular myocardium from Trpm4-/- mice. Circ.Res. 2014; 2: 283294.

25. Mathar I, Vennekens R, Meissner M, Kees F, Van der Mieren G, Camacho Londono JE, Uhl S, Voets T, Hummel B, van den Bergh A, Herijgers P, Nilius B, Flockerzi V, Schweda $\mathrm{F}$ and Freichel $\mathrm{M}$. Increased catecholamine secretion contributes to hypertension in TRPM4-deficient mice. J.Clin.Invest. 2010; 9: 3267-3279.

26. Mathar I, Jacobs G, Kecskes M, Menigoz A, Philippaert K and Vennekens R. Trpm4. Handb.Exp.Pharmacol. 2014; 461-487.

27. Liu H, Chatel S, Simard C, Syam N, Salle L, Probst V, Morel J, Millat G, Lopez M, Abriel H, Schott JJ,
Guinamard R and Bouvagnet P. Molecular genetics and functional anomalies in a series of 248 Brugada cases with 11 mutations in the TRPM4 channel. PLoS One. 2013; 1: e54131.

28. Stallmeyer B, Zumhagen S, Denjoy I, Duthoit G, Hebert JL, Ferrer X, Maugenre S, Schmitz W, Kirchhefer U, SchulzeBahr E, Guicheney P and Schulze-Bahr E. Mutational spectrum in the $\mathrm{Ca}(2+)$--activated cation channel gene TRPM4 in patients with cardiac conductance disturbances. Hum.Mutat. 2012; 1: 109-117.

29. Grand T, Demion M, Norez C, Mettey Y, Launay P, Becq F, Bois P and Guinamard R. 9-phenanthrol inhibits human TRPM4 but not TRPM5 cationic channels. Br.J.Pharmacol. 2008; 8: 1697-1705.

30. Abriel H, Syam N, Sottas V, Amarouch MY and Rougier JS. TRPM4 channels in the cardiovascular system: physiology, pathophysiology, and pharmacology. Biochem. Pharmacol. 2012; 7: 873-881.

31. Kecskes M, Jacobs G, Kerselaers S, Syam N, Menigoz A, Vangheluwe P, Freichel M, Flockerzi V, Voets T and Vennekens $\mathrm{R}$. The $\mathrm{Ca}(2+)$-activated cation channel TRPM4 is a negative regulator of angiotensin II-induced cardiac hypertrophy. Basic Res.Cardiol. 2015; 4: 43-015-0501-x. Epub 2015 Jun 5.

32. Jacobs G, Oosterlinck W, Dresselaers T, Geenens R, Kerselaers S, Himmelreich U, Herijgers $P$ and Vennekens R. Enhanced beta-adrenergic cardiac reserve in Trpm4(-)/(-) mice with ischaemic heart failure. Cardiovasc.Res. 2015; 3: 330-339.

33. Piao H, Takahashi K, Yamaguchi Y, Wang C, Liu K and Naruse K. Transient receptor potential melastatin-4 is involved in hypoxia-reoxygenation injury in the cardiomyocytes. PLoS One. 2015; 4: e0121703.

34. Sarmiento D, Montorfano I, Cerda O, Caceres M, Becerra A, Cabello-Verrugio C, Elorza AA, Riedel C, Tapia P, Velasquez LA, Varela D and Simon F. Increases in reactive oxygen species enhance vascular endothelial cell migration through a mechanism dependent on the transient receptor potential melastatin 4 ion channel. Microvasc.Res. 2015; 187-196.

35. Shimizu T, Owsianik G, Freichel M, Flockerzi V, Nilius B and Vennekens R. TRPM4 regulates migration of mast cells in mice. Cell Calcium. 2009; 3: 226-232.

36. Barbet G, Demion M, Moura IC, Serafini N, Leger T, Vrtovsnik F, Monteiro RC, Guinamard R, Kinet JP and Launay P. The calcium-activated nonselective cation channel TRPM4 is essential for the migration but not the maturation of dendritic cells. Nat.Immunol. 2008; 10: 11481156.

37. Armisen R, Marcelain K, Simon F, Tapia JC, Toro J, Quest AF and Stutzin A. TRPM4 enhances cell proliferation through up-regulation of the beta-catenin signaling pathway. J.Cell.Physiol. 2011; 1: 103-109.

38. Schinke EN, Bii V, Nalla A, Rae DT, Tedrick L, Meadows 
GG and Trobridge GD. A novel approach to identify driver genes involved in androgen-independent prostate cancer. Mol.Cancer. 2014; 1: 120-4598-13-120.

39. Ashida S, Nakagawa $H$, Katagiri T, Furihata M, Iiizumi M, Anazawa Y, Tsunoda T, Takata R, Kasahara K, Miki T, Fujioka T, Shuin T and Nakamura Y. Molecular features of the transition from prostatic intraepithelial neoplasia (PIN) to prostate cancer: genome-wide gene-expression profiles of prostate cancers and PINs. Cancer Res. 2004; 17: 59635972.

40. Simard JM, Woo SK and Gerzanich V. Transient receptor potential melastatin 4 and cell death. Pflugers Arch. 2012; 6: 573-582.

41. Liu W, Lu M, Liu B, Huang Y and Wang K. Inhibition of $\mathrm{Ca}(2+)$-activated $\mathrm{Cl}(-)$ channel ANO1/TMEM16A expression suppresses tumor growth and invasiveness in human prostate carcinoma. Cancer Lett. 2012; 1: 41-51.

42. Nilius B, Prenen J, Janssens A, Voets T and Droogmans G. Decavanadate modulates gating of TRPM4 cation channels. J.Physiol. 2004; Pt 3: 753-765.

43. Cheng H, Beck A, Launay P, Gross SA, Stokes AJ, Kinet JP, Fleig A and Penner R. TRPM4 controls insulin secretion in pancreatic beta-cells. Cell Calcium. 2007; 1: 51-61.

44. Beck A, Penner R and Fleig A. Lipopolysaccharide-induced down-regulation of $\mathrm{Ca} 2+$ release-activated $\mathrm{Ca} 2+$ currents (I CRAC) but not Ca2+-activated TRPM4-like currents (I CAN) in cultured mouse microglial cells. J.Physiol. 2008; 2: 427-439.

45. Holzmann C, Kilch T, Kappel S, Armbruster A, Jung V, Stockle M, Bogeski I, Schwarz EC and Peinelt C. ICRAC controls the rapid androgen response in human primary prostate epithelial cells and is altered in prostate cancer. Oncotarget. 2013; 11: 2096-2107.

46. Wei C, Wang X, Chen M, Ouyang K, Song LS and Cheng H. Calcium flickers steer cell migration. Nature. 2009; 7231: 901-905.

47. Wei $\mathrm{C}$, Wang $\mathrm{X}$, Zheng $\mathrm{M}$ and Cheng $\mathrm{H}$. Calcium gradients underlying cell migration. Curr.Opin.Cell Biol. 2012; 2: 254-261.

48. Tsai FC, Seki A, Yang HW, Hayer A, Carrasco $\mathrm{S}$, Malmersjo $\mathrm{S}$ and Meyer $\mathrm{T}$. A polarized $\mathrm{Ca} 2+$, diacylglycerol and STIM1 signalling system regulates directed cell migration. Nat.Cell Biol. 2014; 2: 133-144.

49. Weber KS, Hildner K, Murphy KM and Allen PM. Trpm4 differentially regulates Th1 and Th2 function by altering calcium signaling and NFAT localization. J.Immunol. 2010; 5: 2836-2846.

50. Caceres M, Ortiz L, Recabarren T, Romero A, Colombo A, Leiva-Salcedo E, Varela D, Rivas J, Silva I, Morales D, Campusano C, Almarza O, Simon F, Toledo H, Park KS, Trimmer JS and Cerda O. TRPM4 Is a Novel Component of the Adhesome Required for Focal Adhesion Disassembly, Migration and Contractility. PLoS One. 2015; 6: e0130540.

51. Doan NT, Paulsen ES, Sehgal P, Moller JV, Nissen P,
Denmeade SR, Isaacs JT, Dionne CA and Christensen SB. Targeting thapsigargin towards tumors. Steroids. 2014.

52. Linxweiler M, Schorr S, Schauble N, Jung M, Linxweiler J, Langer F, Schafers HJ, Cavalie A, Zimmermann R and Greiner M. Targeting cell migration and the endoplasmic reticulum stress response with calmodulin antagonists: a clinically tested small molecule phenocopy of SEC62 gene silencing in human tumor cells. BMC Cancer. 2013; 5742407-13-574.

53. Becerra A, Echeverria C, Varela D, Sarmiento D, Armisen R, Nunez-Villena F, Montecinos M and Simon F. Transient receptor potential melastatin 4 inhibition prevents lipopolysaccharide-induced endothelial cell death. Cardiovasc.Res. 2011; 4: 677-684.

54. Gmyrek GA, Walburg M, Webb CP, Yu HM, You $\mathrm{X}$, Vaughan ED, Vande Woude GF and Knudsen BS. Normal and malignant prostate epithelial cells differ in their response to hepatocyte growth factor/scatter factor. Am.J.Pathol. 2001; 2: 579-590.

55. Alansary D, Kilch T, Holzmann C, Peinelt C, Hoth M and Lis A. The Minimal Requirements to Use Calcium Imaging to Analyze ICRAC. Cold Spring Harb Protoc. 2014; 6: pdb. prot073262.

56. Alansary D, Kilch T, Holzmann C, Peinelt C, Hoth M and Lis A. Measuring Endogenous ICRAC and ORAI Currents with the Patch-Clamp Technique. Cold Spring Harb Protoc. 2014; 283-290.

57. Alansary D, Kilch T, Holzmann C, Peinelt C, Hoth M and Lis A. Patch-Clamp Measurement of ICRAC and ORAI Channel Activity. Cold Spring Harb Protoc. 2014; 6: pdb. top066795.

58. Grynkiewicz G, Poenie M and Tsien RY. A new generation of $\mathrm{Ca} 2+$ indicators with greatly improved fluorescence properties. J.Biol.Chem. 1985; 6: 3440-3450. 